\title{
DUKUNGAN SUAMI TERHADAP PEMBERIAN ASI EKSKLUSIF PADA BAYI USIA 6-12 BULAN
}

\author{
HUSBAND SUPPORT WITH EXCLUSIVE BREASTFEEDING \\ ON INFANTS AGED 6-12 MONTHS
}

\author{
Aulia Rahmawati ${ }^{1}$, Budi Susilowati ${ }^{2}$ \\ ${ }^{1}$ Departemen Promosi Kesehatan dan Ilmu Perilaku \\ Fakultas Kesehatan Masyarakat, Universitas Airlangga Surabaya \\ ${ }^{2}$ Staf Pengajar Program D-III Kebidanan, Universitas Aisyiyah Yogyakarta \\ Email: aulia.rahmawati-2015@fkm.unair.ac.id
}

\begin{abstract}
Husband's support having a role in the success or failure of a mother to breastfeed her baby. The greater the support obtained to breastfeed, the greater the ability to survive. This research aimed to know the husband support with exclusive breastfeeding on infants aged 6-12 months. This research is a non experimental. Time approach used in this study is cross-sectional. The sampling technique used purposive sampling. In conducting data analysis of research results using Kendal Tau formula. This research was conducted at Posyandu Dewisari Kenteng Gadingsari Sanden Bantul Yogyakarta. The population in the study were 44 respondents. The samples in the study were 30 respondents, who had infants aged 6 to 12 months. This study showed that the support of husbands in exclusive breastfeeding included in high category as much as 70\%, medium category $6.7 \%$ and low category 23.3\%. The number of mothers who give exclusive breastfeeding in Posyandu Dewisari many as 16 mothers (53.3\%). Mothers who didn't breastfeed exclusively are 14 women (46.7\%). Based on the results of the relationship test is known that there is a relationship of support of the husband with exclusive breastfeeding. It can be concluded if there is a relationship with the husband's support exclusive in breastfeeding. The socialization of the Health Promotion Program needs to be disseminated through various communication media for couples, families and the environment so that husbands'support for exclusive breastfeeding is met. In addition, the husband as the head of the household needs to perform his role as a "support system", so that the mother can give exclusive breastfeeding by providing support, appreciation, emotional and instrumental for mother that breastfeeding the babies until 6 months, so she can give exclusive breastfeeding.
\end{abstract}

Keywords: husband support, exclusive Breastfeeding

\begin{abstract}
Abstrak: Dukungan suami mempunyai peran dalam sukses atau tidaknya seorang ibu dalam menyusui bayinya. Semakin besar dukungan yang didapatkan untuk menyusui bayinya maka semakin besar kemampuan untuk bertahan dalam menyusui. Penelitian ini mempunyai tujuan untuk mengetahui hubungan dukungan suami dengan pemberian ASI eksklusif pada bayi usia 6 sampai 12 bulan. Penelitian ini merupakan penelitian non eksperimental. Pendekatan waktu yang digunakan dalam penelitian yaitu cross sectional. Teknik pengambilan sampel penelitian menggunakan purposive sampling. Dalam melakukan analisis data hasil penelitian menggunakan rumus Kendal Tau. Penelitian ini dilakukan di Posyandu Dewisari Kenteng Gadingsari Sanden Bantul Yogyakarta. Jumlah populasi dalam penelitian sebanyak 44 responden. Sampel pada penelitian berjumlah 30 responden, yaitu ibu menyusui yang memiliki bayi berumur 6 sampai 12 bulan. Penelitian ini menunjukkan hasil bahwa dukungan suami dalam pemberian ASI eksklusif termasuk dalam kategori tinggi sebanyak 70\%, kategori sedang 6,7\% dan kategori rendah 23,3\%. Jumlah ibu yang memberikan ASI eksklusif sebanyak $16 \mathrm{ibu}(53,3 \%)$. Ibu yang tidak memberikan ASI ekslusif sebanyak $14 \mathrm{ibu}$ (46,7\%). Berdasarkan hasil uji hubungan diketahui bahwa terdapat hubungan dukungan suami dengan pemberian ASI eksklusif. Sehingga dapat disimpulkan terdapat hubungan dukungan suami dengan pemberian ASI eksklusif pada ibu menyusui yang mempunyai bayi usia 6 sampai 12 bulan. Sosialisasi program Promosi Kesehatan perlu disebarluaskan melalui berbagai media komunikasi untuk pasangan suami istri, keluarga dan lingkungan agar dukungan suami terhadap pemberian ASI eksklusif terpenuhi. Selain itu, suami sebagai kepala rumah tangga perlu menjalankan perannya sebagai "support system" dengan memberikan dukungan informatif, penghargaan, emosional dan instrumental selama ibu menyusui sampai bayi berusia 6 bulan sehingga ibu dapat memberikan ASI eksklusif.
\end{abstract}

Kata kunci: dukungan suami, pemberian ASI eksklusif 


\section{PENDAHULUAN}

Budaya menyusui pada bayi di Indonesia merupakan sesuatu hal yang penting bagi ibu yang memiliki bayi. Akan tetapi, praktek dalam pemberian Air Susu Ibu (ASI) eksklusif belum mencapai target yang diharapkan. Di Indonesia, nilai AKB atau angka kematian bayi termasuk tinggi, jika dibandingkan pada beberapa negara ASEAN. Human Development Report (2010), merilis data bahwa AKB di Indonesia mencapai 31/1.000 angka kelahiran. Nilai tersebut, lebih tinggi sebanyak 2,4 kali dibandingkan Thailand dan lebih tinggi sebanyak 1,2 kali dibandingkan Filipina. Bahkan nilai AKB di Indonesia tersebut, lebih tinggi 5,2 kali jika dibandingkan dengan Malaysia.

Peningkatan AKB dipengaruhi oleh meningkatnya bayi yang tidak diberikan ASI eksklusif. Pada agenda Millenium Development Goal's (MDG's), penurunan nilai AKB pada Tahun 2015 ditargetkan sebanyak 23 dari 1.000 angka kelahiran. Akan tetapi, sebagian besar wilayah di Indonesia seperti di Yogyakarta masih memiliki nilai AKB yang tinggi, yaitu sebanyak 25 per 1.000 angka kelahiran (Profil Kesehatan DIY, 2013). AKB adalah hal yang cukup penting dan perlu dipertimbangkan penanganannya dalam rangka menurunkan nilainya. Hal tersebut dilakukan agar target MDG's dapat tercapai. Peningkatan AKB dapat dihindari dengan melakukan pemberian ASI kepada bayi pada saat hari pertama lahir. Apabila pemberian ASI dilakukan 1 jam pertama setelah kelahiran bayi akan meningkatkan persentase keselamatan bayi sebanyak $22 \%$ (Roesli, 2008).

ASI merupakan makanan pertama, utama dan terbaik bagi bayi sampai bayi berumur 6 bulan yang bersifat alamiah. ASI diberikan sedini mungkin setelah persalinan dan tanpa jadwal. ASI mengandung berbagai zat gizi yang dibutuhkan dalam proses pertumbuhan dan perkembangan bayi (Prasetyono,2009). Berdasarkan Hasil Survei Demografi Kesehatan Indonesia pada tahun 2007, diketahui bahwa $10 \%$ bayi mendapatkan ASI pada saat hari pertama setelah lahir sedangkan bayi yang mendapatkan ASI kurang dari 2 bulan sebanyak $73 \%$. Jumlah bayi yang diberikan
ASI antara 2 hingga 3 bulan dan bayi yang diberikan ASI antara 4 hingga 5 bulan masing-masing sebanyak $53 \%$ dan $20 \%$. Bayi yang diberikan ASI secara eksklusif pada bayi dengan usia sampai 6 bulan yakni sebanyak $49 \%$.

Variatifnya pemberian ASI eksklusif kepada bayi dikarenakan adanya tindakan pemberian makanan pendamping ASI (MPASI) yang dilakukan oleh ibu. Pemberian MP-ASI pada usia dini di Indonesia tergolong cukup besar, yaitu diketahui bahwa pemberian makan pendukung pada bayi yang berusia kurang dari 2 bulan dan usia antara $2-3$ bulan mencapai angka masing-masing $12 \%$ dan $27 \%$ (Survei Demografi Kesehatan Indonesia, 2007)

MP-ASI yang diberikan kepada bayi yang berusia 0 sampai 3 bulan, dapat mengakibatkan kurangnya pemberian ASI eksklusif karena bayi akan sering merasa kenyang (Widya Wko, Wahyu Retno, Hartiti Tri dan Samiasih, 2011). Seharusnya pada usia 0 sampai 3 bulan, bayi hanya mendapatkan ASI eksklusif saja. Karena idealnya, bayi diberikan ASI eksklusif pada usia 0 sampai 6 bulan. Apabila diketahui berusia di bawah 6 bulan telah diberikan makanan pendamping, akan menimbulkan berbagai masalah seperti terjangkitnya berbagai jenis penyakit yang dapat mengakibatkan kematian pada bayi. Oleh karena itu, pemberian ASI eksklusif sangat dianjurkan untuk kesehatan bayi.

Beberapa masyarakat masih memiliki pikiran bahwa menyusui merupakan urusan ibu dan bayinya. Padahal dalam kegiatan menyusui, interaksi antara ibu dengan suami dibutuhkan. Interaksi dapat berupa dukungan suami kepada ibu yang menyusui. Interaksi tersebut berdampak terhadap praktek pemberian ASI eksklusif. Oleh karena itu, adanya dukungan suami dalam pemberian ASI eksklusif kepada ibu menyusui sangat dibutuhkan. Dukungan dari suami dapat meningkatkan persepsi, motivasi, emosi dan sikap ibu. Selama ini, suami menganggap dirinya hanya sebagai pengamat pasif pada proses pemberian ASI eksklusif, padahal dukungan mereka memiliki peran dalam sikap dan perilaku ibu dalam menyusui bayinya. Semakin besarnya dukungan yang didapatkan seorang ibu dari 
suami untuk menyusui, maka akan semakin tinggi juga kemampuan dan kemauan ibu dalam menyusui bayinya (Proverawati, Atikah dan Rahmawati Eni, 2010)

ASI yang keluar pertama kalinya dari ibu yang baru melahirkan, mengandung zat yang bermanfaat sebagai antibodi yang mencegah berbagai penyakit seperti gangguan pencernaan, radang paru, batuk rejan dan radang otak. Selain manfaat kepada bayi, ibu yang segera menyusui bayinya setelah bayinya lahir, memperoleh keuntungan yakni mengurangi risiko pendarahan dan rahimnya cepat mengecil (Suradi, 2008).

Banyaknya informasi tentang manfaat ASI tidak diiringi dengan meningkatnya kesadaran ibu dalam menyusui bayinya. Banyak masyarakat, khususnya bagi kaum wanita yang tidak memahami manfaat dan pentingnya ASI (Suradi R, Hegar B, Partiwi A.N, Marzuki N.S, Ananta Y, 2010). Rendahnya keinginan dalam pemberian ASI, disebabkan karena mereka lebih cenderung mengikuti hal-hal yang sifatnya modern. Beberapa ibu beranggapan bahwa pemberian susu botol jauh lebih praktis daripada menyusui bayinya. Dan juga banyak ibu tidak mau menyusui bayinya karena akan mengurangi kecantikannya, dimana mereka beranggapan bahwa dengan menyusui bayi akan menyebabkan payudaranya kendor.

Terdapat beberapa faktor yang menyebabkan keberhasilan dan kegagalan dalam menyusui. Faktor-faktor tersebut yakni dukungan suami, dukungan emosional pada masa post-partum, hubungan keluarga, persoalan dan kesulitan fisik, nilai-nilai yang diterapkan masyarakat serta proses laktasi pada masa terdahulu yang dianggap berhasil (Depkes, 2005). Rendahnya pencapaian dalam pemberian ASI eksklusif oleh ibu menyusui, sangat terkait dengan dukungan suami. Hal tersebut merupakan faktor yang memiliki andil cukup besar terhadap kondisi psikis ibu saat menyusui. Kondisi psikis ibu yang tidak stabil serta kurangnya dukungan suami dalam pemberian ASI ekslusif dapat mengurangi produksi ASI ekslusif pada ibu.

Persentase pemberian ASI ekslusif di Provinsi Yogyakarta, khususnya pada bayi dengan usia 0 sampai 6 bulan tergolong belum stabil. Pemberian ASI eksklusif mengalami perubahan fluktuatif dari tahun ke tahun (terjadi peningkatan dan penurunan). Pemberian ASI eksklusif pada tahun 2008 hanya sebesar 39,9\% dan angka tersebut mengalami penurunan menjadi $34,56 \%$ pada tahun 2009. Namun, kemudian meningkat pada tahun 2010 sebesar 40,03\%. Pemberian ASI eksklusif pada tahun 2011, mengalami peningkatan lagi sebesar $49,5 \%$. Akan tetapi, pemberian ASI eksklusif pada tahun 2012 menunjukkan penurunan kembali menjadi 48\% (Profil Kesehatan DIY, 2013).

Capaian dalam pemberian ASI eksklusif di Provinsi D.I. Yogyakarta telah ditetapkan sebesar $60 \%$ dalam rencana strategis instansi pemerintahan Provinsi D.I. Yogyakarta melalui Dinas Kesehatan. Namun, nilai capaian beberapa kabupaten di wilayah provinsi tersebut masih di bawah nilai capaian yang telah ditetapkan dalam rencana strategis. Cakupan Pemberian ASI eksklusif Kabupaten Sleman di bawah 60\%, Kabupaten Bantul hanya 50\%, Kabupaten Kulonprogo hanya 40\% dan Kabupaten Gunung Kidul hanya 39\%, (Profil Kesehatan DIY, 2013).

Berdasarkan persentase cakupan pemberian ASI eksklusif di Provinsi D.I. Yogyakarta tersebut, dapat diperhatikan bahwa persentase pemberian ASI ekslusif pada semua kabupaten belum ada yang memenuhi target, salah satunya adalah Kabupaten Bantul. Rendahnya pemberian ASI eksklusif di beberapa kabupaten di Provinsi D.I. Yogyakarta, khususnya di Kabupaten Bantul dikarenakan beberapa faktor. Rendahnya dukungan dari suami kepada ibu yang menyusui bayinya dalam memberikan ASI eksklusif merupakan suatu faktor yang menyebabkan target dalam pemberian ASI eksklusif belum tercapai di Kabupaten Bantul.

Hasil studiawal yang telah dilakukan pada Posyandu Dewisari di Kabupaten Bantul, Yogyakarta tanggal 25 Januari 2013, diketahui bahwa terdapat $17 \mathrm{ibu}$ yang menyusui bayinya optimal (kurang dari 6 bulan) dari 30 ibu yang diwawancarai. Rendahnya dukungan suami serta tuntutan 
pekerjaan menjadi alasan yang membuat ibu tidak memberikan ASI ekslusif. Beberapa suami membiarkan istrinya bekerja pada saat masa menyusui dan tidak memperhatikan istrinya apabila tidak memberikan ASI eksklusif kepada bayi.

Menurut hasil kegiatan studi awal yang telah dilakukan dengan mewawancarai 30 ibu, didapatkan bahwa sebagian ibu bekerja di rumah dan di luar rumah. Selain faktor tuntutan pekerjaan, rendahnya pemberian ASI juga dikarenakan beberapa ibu yang menyusui merasa tidak puas jika bayinya hanya memperoleh ASI. Ketidakpuasan tersebut dikarenakan jumlah ASI yang dihasilkan sedikit. Sehingga, akibat ketidakpuasan tersebut mengakibatkan ibu memberikan makanan tambahan lain berupa susu formula.

Berdasarkan data pemberian ASI eksklusif yang didapatkan dari Puskesmas Sanden, Kabupaten Bantul Yogyakarta diketahui bahwa ASI eksklusif yang diberikan pada bayi yang berusia sampai usia 6 bulan hanya 55,8\% (Profil Kesehatan Kabupaten Bantul, 2012). Data yang didapat memberikan gambaran mengenai tingkat kesadaran ibu-ibu yang memiliki bayi yang tergolong masih rendah dan masih di bawah target capaian di Provinsi D.I. Yogyakarta dalam memberikan ASI eksklusif. Dari uraian data dan informasi tersebut, tujuan umum penelitian ini dilakukan untuk mengetahui dukungan suami terhadap pemberian ASI eksklusif pada bayi dengan usia 6 sampai 12 bulan. Sedangkan tujuan khusus dalam penelitian ini yaitu diketahuinya dukungan suami terhadap pemberian ASI ekslusif pada bayi usia 6 sampai 12 bulan dan diketahuinya pemberian ASI eksklusif pada bayi usia 6 sampai 12 bulan.

\section{METODE}

Penelitian ini telah dilaksanakan pada tanggal 5 Juni tahun 2013. Penelitian yang dilakukan merupakan penelitian yang bersifat non eksperimental. Adapun pendekatan waktu dalam penelitian ini menggunakan pendekatan cross sectional.

Sampel penelitian yang digunakan dalam penelitian ini sebanyak 30 responden dari 44 responden yang telah memiliki bayi berusia 6 sampai 12 bulan. Adapun teknik yang digunakan dalam pengambilan sampel penelitian adalah teknik purposive sampling. Adapun dalam melakukan analisis data hasil penelitian ini dengan menggunakan rumus Kendal Tau. Data dalam penelitian ini berbentuk ordinal dan nominal. Untuk memperoleh data penelitian ditetapkan kriteria inklusi sampel data. Kriteria inklusi sampel data dalam penelitian yaitu ibu yang menyusui dengan syarat memiliki bayi berusia 6 hingga 12 bulan, mempunyai pendidikan minimal tamat sekolah dasar, tidak mengalami kelainan pada payudara serta tidak memiliki penyakit menurun, menahun dan menular.

Adapun variabel yang ditentukan dalam penelitian diantaranya variabel bebas dan variabel terikat. Adapun variabel bebas yang digunakan dalam penelitian yakni dukungan suami, sedangkan variabel terikat yakni tingkat pemberian ASI eksklusif. Sedangkan data karakteristik responden terdiri dari tingkat kesehatan responden, jenjang pendidikan responden, status pekerjaan saat ini, lingkungan sekitar responden, pengalaman yang dialami responden serta dukungan dari tenaga kesehatan. Dalam menilai ketiga variable penelitian digunakan instrumen penelitian berupa kuesioner.

Untuk penilaian variabel bebas digunakan kuesioner dukungan suami. Adapun jumlah pertanyaan untuk kuesioner dukungan suami sebanyak 25 soal. Bentuk penilaian akhir dari variabel ini adalah skor tinggi dengan nilai 76-100, jika jumlah soal yang dijawab benar oleh responden sebanyak 18-23 soal. Skor sedang dengan nilai 56-75, jika jumlah soal yang dijawab benar oleh responden sebanyak 12-17 soal. Skor rendah dengan nilai 40-55, jika jumlah soal yang dijawab benar sebanyak 9-13 soal (Sulistyaningsih, 2011).

Penilaian variabel terikat penelitian ini menggunakan kuesioner pemberian ASI eksklusif dengan jumlah pertanyaan sebanyak dua soal. Peroleh skor tinggi dengan kode jawaban 2 jika responden memberikan ASI eksklusif, dimana responden menjawab "ya" pada kedua pertanyaan yang disampaikan. Sedangkan skor rendah dengan jawaban 1 jika 
responden tidak memberikan ASI eksklusif, dimana responden hanya menjawab ya pada satu pertanyaan saja atau jawaban tidak pada kedua pertanyaan yang disampaikan. Data yang diperoleh dari hasil analisis kemudian diuji menggunakan rumus Kendal Tau, dengan nilai uji signifikansi $(\alpha)$ sebesar $5 \%$. Dimana, apabila $\alpha \leq 5 \%$, hipotesis dalam penelitian dapat diterima apabila $\alpha \geq 5 \%$ maka hipotesis dalam penelitian ini ditolak.

\section{HASIL PENELITIAN}

Penelitian dilaksanakan di Posyandu Dewisari. Posyandu Dewisari merupakan salah satu posyandu yang terletak di Kecamatan Sanden, Kabupaten Bantul, Yogyakarta. Posyandu Dewisari memiliki letak dengan batas di bagian utara yakni Dusun Puluhan Kelurahan Trimurti (Kecamatan Srandakan), bagian timur yaitu Dusun Ngentak Kelurahan Murtigading (Kecamatan Sanden), bagian selatan dengan Dusun Pucanganom Kelurahan Murtigading (Kecamatan Sanden) serta bagian barat dengan Dusun Gambrengan (Kecamatan Srandakan).

Kegiatan di posyandu dilaksanakan rutin setiap bulan tepatnya tanggal 5 (lima), yang berlokasi di rumah Kepala Dusun. Setiap 3 bulan sekali, kegiatan posyandu akan ditangani langsung oleh kader (petugas kesehatan) dari Puskesmas Sanden. Kader berpartisipasi aktif dalam memotivasi ibu yang memiliki bayi dan balita agar mengikuti posyandu secara rutin. Kader yang aktif dalam kegiatan Posyandu sebanyak 6 orang. Adapun kegiatan posyandu yang dilakukan meliputi pemeriksaan fisik yaitu penimbangan berat badan, pemberian penyuluhan tentang kesehatan dan pemberian makanan tambahan bagi balita seperti bubur kacang hijau.

Berdasarkan tabel diatas dapat diketahui bahwa sebagian besar responden yang mempunyai bayi usia 6-12 bulan berada pada katagori Wanita Usia Subur. Usia responden tidak berhubungan dengan tingkat pemberian ASI eksklusif pada ibu menyusui. Hal tersebut dibuktikan dengan hasil uji data yang menggunakan rumus Kendal Tau dengan nilai $p_{\text {value }}$ sebanyak 0,006 . Seluruh
Tabel 1. Karakteristik Responden Berdasarkan Umur, Tingkat Pendidikan, Pekerjaan, Riwayat Penyakit dan Suku Responden di Posyandu Dewisari Bulan Juni Tahun 2013

\begin{tabular}{lcc}
\hline Karakteristik & Frekuensi & \% \\
\hline Umur & 15 & 50 \\
$20-27$ & 11 & 36,7 \\
$28-35$ & 4 & 13,3 \\
$36-43$ & $\mathbf{3 0}$ & $\mathbf{1 0 0}$ \\
\hline Total & 1 & 3,3 \\
\hline Tingkat Pendidikan & & 90 \\
$\quad$ SMP & 27 & 6,7 \\
SMA & 2 & $\mathbf{1 0 0}$ \\
$\quad$ Diploma & $\mathbf{3 0}$ & \\
\hline Total & 9 & 30 \\
\hline Pekerjaan & 1 & 3,3 \\
$\quad$ Wiraswasta & 20 & 66,7 \\
PNS & $\mathbf{3 0}$ & $\mathbf{1 0 0}$ \\
$\quad$ IRT & & \\
\hline Total & 8 & 100 \\
\hline Riwayat Penyakit & 0 & 0 \\
$\quad$ Ya & $\mathbf{3 0}$ & $\mathbf{1 0 0}$ \\
Tidak & & \\
\hline Total & 27 & 90 \\
\hline Suku & 3 & 10 \\
$\quad$ Jawa & & $\mathbf{3 0}$ \\
Non Jawa & & \\
\hline Total & & \\
\hline
\end{tabular}

responden pernah mengenyam pendidikan sehingga dapat diajak untuk wawancara. Tingkat pendidikan berhubungan dengan tingkat pemberian ASI seorang ibu yang menyusui. Hal tersebut dibuktikan dengan hasil uji data yang menggunakan rumus Kendal Tau dengan nilai $p_{\text {value }}$ sebanyak 0,003 . Bukan hanya pendidikan ibu tapi pendidikan dari suami juga sangat dibutuhkan. Semakin tinggi tingkat pendidikan seorang suami, maka semakin tinggi pemahamannya akan pentingnya ASI dan risiko yang dapat terjadi jika bayi tidak diberikannya ASI eksklusif. Akan tetapi hubungan pendidikan suami juga dapat berdampak negatif terhadap dukungan dalam pemberian ASI. Tingginya tingkat Pendidikan yang dimiliki seorang suami menyebabkan pekerjaan yang ditekuninya akan berada di lingkungan publik yang lokasi dan intensitasnya lebih banyak di luar rumah. Sehingga kondisi tersebut dapat 
meningkatkan keikutsertaan suami dalam memperhatikan tumbuh kembang anaknya.

Seluruh responden mempunyai pekerjaan yang berbeda sehingga dapat berhubungan dalam pemberian ASI eksklusif. Hal tersebut dibuktikan dengan hasil uji data yang menggunakan rumus Kendal Tau dengan nilai $p_{\text {value }}$ sebanyak 0,001 . Sebagian responden yang bekerja tidak memberikan ASI secara eksklusif karena kesibukannya. Sebagian besar responden mempunyai pekerjaan sebagai ibu rumah tangga dan penghasilan mereka tidak menentu atau tidak tetap. Secara umum, tingkat sosial ekonomi berhubungan terhadap pola perilaku kesehatan masyarakat. Masyarakat dengan kemampuan ekonomi tinggi, akan memanfaatkan fasilitas kesehatan dengan kualitas yang baik dan bagus dengan dampak biaya yang lebih mahal. Sedangkan masyarakat yang memiliki tingkat ekonomi menengah ke bawah, tentunya akan menggunakan fasilitas kesehatan sesuai dengan kemampuan ekonominya, sehingga informasi dan fasilitas yang diperoleh pun terbatas

Seluruh responden tidak mempunyai riwayat penyakit sehingga tidak mempunyai penghambat dari faktor kesehatan dalam pemberian ASI eksklusif. Riwayat kesehatan responden berhubungan dengan tingkat pemberian ASI eksklusif ibu yang menyusui. Hal tersebut dibuktikan dengan hasil uji data yang menggunakan rumus Kendal Tau dengan nilai $p_{\text {value }}$ sebanyak 0,003 Sebagian besar responden berasal dari suku jawa yang mempunyai budaya dalam mengasuh bayi. Mereka cenderung merawat bayi dengan kasih sayang dan perhatian. Asal suku responden tidak berhubungan dengan tingkat pemberian ASI seorang ibu menyusui. Hal tersebut dibuktikan dengan hasil uji data yang menggunakan rumus Kendal Tau dengan nilai $p_{\text {value }}$ sebanyak 0,006 .

Dukungan Suami Terhadap Pemberian ASI eksklusif Pada Bayi Usia 6-12 Bulan di Posyandu Dewisari.

Sebagian besar ibu yang mempunyai bayi pada usia 6 sampai 12 bulan pada lokasi penelitian mendapat dukungan yang tinggi dalam pemberian ASI eksklusif berupa dukungan dari suami. Skor dalam dukungan
Tabel 2. Distribusi Frekuensi Dukungan Suami terhadap Pemberian ASI Eksklusif di Posyandu Dewisari Bulan Juni Tahun 2013

\begin{tabular}{lcc}
\hline Dukungan & Frekuensi & \% \\
\hline Tinggi & 21 & 70 \\
Sedang & 2 & 6,7 \\
Rendah & 7 & 23,3 \\
\hline Total & $\mathbf{3 0}$ & $\mathbf{1 0 0}$ \\
\hline
\end{tabular}

pemberian ASI eksklusif dikatakan tinggi jika responden dapat menjawab soal dengan benar sebanyak 18-23 soal dengan skor 76-100. Responden yang mempunyai skor tinggi sebanyak 21 responden. Responden memperoleh skor tinggi karena mereka dapat menjawab pertanyaan dengan tingkat kesalahan sedikit. Hal ini dipengaruhi oleh pengetahuan responden yang dapat dilihat dari tingkat pendidikan. Umur responden yang termasuk dalam kategori Wanita Usia Subur juga berpengaruh dalam tingginya dukungan menyusui. Hal ini karena responden masih produktif dalam pemberian ASI eksklusif. Skor sedang dengan nilai 56-75, jika jumlah soal yang dijawab benar oleh responden sebanyak 12-17 soal. Skor rendah dengan nilai 40-55, jika jumlah soal yang dijawab benar sebanyak 9-13 soal (Sulistyaningsih, 2011).

Dari hasil analisis kuesioner dukungan suami, diketahui bahwa terdapat empat dukungan yang diberikan oleh suami pada pemberian ASI eksklusif yakni dukungan informatif, dukungan penghargaan, dukungan emosional dan dukungan instrumental. Adapun hasil penilaian dukungan suami melalui dukungan informatif sebesar $69,7 \%$ dengan jumlah skor 209. Dari data tersebut diketahui bahwa dukungan informatif menempati peringkat tertinggi. Hal ini menunjukkan

Tabel 3. Dukungan Suami pada Pemberian ASI Eksklusif per Item Soal

\begin{tabular}{lcc}
\hline \multicolumn{1}{c}{ Dukungan suami } & $\begin{array}{c}\text { Total } \\
\text { skor }\end{array}$ & Persentase \\
\hline Dukungan Informatif & 209 & 69,7 \\
Dukungan Penghargaan & 101 & 33,7 \\
Dukungan Emosional & 178 & 17,8 \\
Dukungan Instrumental & 153 & 51,0 \\
\hline Total & $\mathbf{6 4 1}$ & $\mathbf{1 7 2 , 2}$ \\
\hline
\end{tabular}


bahwa suami mendukung istri dalam pemberian ASI eksklusif melalui informasi kesehatan yang diberikan. Dukungan informatif dapat diberikan apabila individu tidak dapat menyelesaikan masalah atau individu membutuhkan hal terkait informasi, dukungan pikiran saran, nasehat, dan petunjuk dalam memecahkan masalahnya. Informasi yang diberikan dapat berasal dari buku ataupun majalah.

Pengetahuan dalam pemberian ASI eksklusif bagi bayi sangat diperlukan oleh seorang suami. Hal ini dikarenakan, pemberian ASI eksklusif bukan sepenuhnya menjadi tanggung jawab seorang ibu, namun peran seorang suami juga diperlukan. Tanpa adanya pengetahuan, maka dimungkinkan seorang suami tidak dapat memberikan dukungan. Menurut Smet (1994), dukungan informatif merupakan perilaku yang berhubungan dengan penyampaian informasi seperti pemberian nasehat. Dukungan informatif dilakukan dengan memberikan penjelasan terkait suatu gejala terkait masalah atau sesuatu hal yang sedang dihadapi oleh individu.

Suatu dukungan yang diberikan seorang suami kepada istri yang menyusui bayinya adalah salah satu penentu keberhasilan dalam pemberian ASI eksklusif. Menurut Hidayat (2009), rangsangan psikologis yang positif akan meningkatkan produktivitas ASI ibu menyusui yang diberikan melalui dukungan suami. Peran suami dapat meningkatkan optimistik atau sikap percaya diri bagi para ibu pada saat menyusui bayinya. Peran suami melalui sebuah dukungan dapat meningkatkan keinginan ibu yang sedang menyusui dan mempunyai bayi berusia 6 hingga 12 bulan agar mau melakukan pemberian ASI ekslusif. Dukungan tersebut dapat diwujudkan dengan membantu memecahkan masalah yang sedang dihadapi ibu menyusui mengenai informasi pemberian ASI eksklusif. Selain itu, dukungan dapat diwujudkan dengan penyediaan materi dan fasilitas dalam mengatasi berbagai hal yang berkaitan dengan pemberian ASI eksklusif. Peran suami berupa dukungan pendapat dan masukan dapat menjaga kondisi fisik dan psikis ibu dalam menyusui agar jauh lebih baik.
Sedangkan dukungan penghargaan sebesar 33,7\% dengan jumlah skor 101 . Dukungan penghargaan adalah dukungan keluarga yang membuat orang yang merasakannya mempunyai perasaan bahwa kita mempunyai nilai. Nilai termasuk dalam penghargaan diri yang merupakan suatu bagian dari manajemen stress (Asnawi, 2009). Dukungan penghargaan dapat berupa ungkapan penghargaan kepada orang lain seperti dukungan untuk terus maju dan persetujuan terhadap gagasan dan perasaan seseorang yang dapat meningkatkan penghargaan diri orang yang menerima dukungan. Seorang ibu mendapatkan dukungan berupa penghargaan dari seseorang yang berada dalam lingkungan keluarganya yaitu suami.

Dukungan emosional sebanyak $17,8 \%$ dengan skor 178. Dukungan ini dapat diberikan dengan pemberian perhatian dan kepedulian sehingga ibu menyusui dapat merasakan ketenangan jiwa. Ungkapan empati, perhatian, kepercayaan, didengarkan dan mendengarkan merupakan bentukbentuk dari dukungan emosional. Sebuah keluarga merupakan tempat yang tentram, nyaman serta damai untuk istirahat dan mengembalikan masa pemulihan. Lingkungan keluarga yang tentram dapat membantu pengendalian terhadap emosi. Dukungan keluarga yang terpenting bagi ibu yang menyusui adalah dari suaminya.

Dukungan emosional dapat berupa sikap dan perilaku yang dapat menimbulkan perasaan nyaman, tenang, senang dan kasih sayang pada seluruh bagian dari sebuah keluarga. Dukungan emosional dapat diterapkan pada anak maupun orang tua. Contoh dukungan emosional antara lain suami memberikan perhatian dan kepedulian yang lebih terhadap keluarga utamanya kepada ibu yang memiliki bayi untuk memberikan ASI eksklusif pada bayinya.

Ibu dapat memberikan perawatan yang baik bagi bayinya terutama dalam pemberian ASI eksklusif apabila mendapat dukungan dari keluarga khususnya dari suami (Asnawi, 2009). Ibu memerlukan dukungan dari orang lain untuk merawat anaknya. Menciptakan kondisi lingkungan yang nyaman bagi ibu sehingga dapat membuat kondisi fisik 
dan psikis ibu menjadi sehat merupakan salah satu peran suami dalam program menyusui. Peningkatan peran suami kepada ibu menyusui dapat merangsang refleks oksitosin sehingga meningkatkan produksi ASI. Pikiran positif pada ibu akan merangsang kontraksi otot sekeliling kelenjar payudara sehingga melancarkan aliran ASI ke sinus laktiferus (aerola) yang kemudian akan di hisap oleh bayi (Roesli, 2008).

Produksi ASI pada ibu yang baru melahirkan terjadi karena adanya efek hormon dan refleks. Pada masa kehamilan, terjadi suatu perubahan yakni perubahan hormon yang menyiapkan jaringan kelenjar susu sehingga dapat memproduksi ASI. Setelah ibu melahirkan, perubahan hormon menyebabkan payudara memproduksi ASI. Bahkan pada beberapa ibu hamil dengan usia kehamilan 6 bulan, perubahan hormon tersebut telah terjadi sehingga pada usia kehamilan tersebut ASI ibu mulai berproduksi. Isapan ASI pada bayi dapat menyebabkan terjadi nya refleks sehingga ASI dapat keluar dengan jumlah yang optimal dan pada kondisi yang tepat (Aprilia, 2010)

Refleks yang terjadi pada ibu menyusui terdiri atas prolaktin reflex (refleks pembentukan) yakni terjadi nya produksi ASI akibat rangsangan hormon prolaktin serta let down reflex (refleks pengaliran) yakni terjadi nya pelepasan ASI akibat rangsangan hormon oksitosin. Hormon prolaktin yang menyebabkan reflex pembentukan dihasilkan dari kelenjar hipofisa depan yang letaknya berada didasar otak. Semakin banyak ASI yang keluar maka akan semakin banyak pula ASI yang terproduksi. Proses pengisapan yang dilakukan oleh bayi akan merangsang saraf di sekitar payudara, sehingga saraf akan mempengaruhi kelenjar hipofisa dalam memproduksi hormon prolaktin (Sherwood, 2009). Hormon prolaktin tersebut, dapat merangsang produksi ASI melalui aliran darah menuju kelenjar payudara.

Sedangkan let down reflex atau refleks pengaliran atau pelepasan ASI dihasilkan dari hormon oksitosin. Hormon oksitosin merupakan hormon yang berasal dari bagian belakang kelenjar hipofisa. Hormon oksitosin akan dihasilkan jika ujung saraf pada payudara mendapatkan rangsangan melalui proses pengisapan, sehingga hormon oksitosin akan mengalir menuju payudara di dalam darah (Ariani, 2010). Bayi tidak mendapatkan ASI secara optimal apabila hanya terdapat salah satu reflex saja yaitu hanya refleks pembentukan ASI atau hanya refleks prolaktin yang bekerja. Namun, harus dibantu refleks pengaliran/ pelepasan ASI atau yang disebut refleks oksitosin. Jika salah satu refleks tersebut tidak berfungsi dengan baik, maka bayi tidak akan memperoleh kualitas dan kuantitas ASI yang memadai, meskipun ASI tersebut tetap terproduksi.

Terdapat beberapa hal yang dapat meningkatkan produksi ASI ibu yang sedang menyusui yaitu memikirkan bayinya dengan kasih sayang dan ibu dalam keadaan tenang. Namun, selain hal yang dapat meningkatkan produksi, juga terdapat hal yang akan menghambat proses keluarnya ASI seperti pikiran negatif menyebabkan terhambatnya refleks oksitosin seperti ibu merasa cemas, sedih, kesal, marah, malu menyusui serta merasa kesakitan saat menyusui. Pada kondisi ini, peran suami menjadi penting dalam meningkatkan kesuksesan ibu menyusui bayinya, terutama dalam menjaga agar refleks oksitosin tetap lancar. Sehingga, keberhasilan menyusui seorang ibu tidak hanya tergantung pada ibu sendiri tetapi juga pada suami.

Dukungan instrumental sebanyak $51,0 \%$ dengan skor 153 . Dukungan ini berupa pemberian materi langsung, seperti menyiapkan fasilitas yang diperlukan, memberi pekerjaan, memberi pinjaman, serta bantuan yang lain (Asnawi, 2009). Dukungan instrumental dapat dilakukan oleh suami dengan menyediakan sarana yang melancarkan aktivitas ibu dalam pemberian ASI eksklusif. Bentuk dukungan ini dapat berupa penyediaan almari es yang digunakan untuk menyimpan ASI yang berlebihan agar dapat tahan lama, menyediakan termos es yang fungsinya sama untuk penyimpanan ASI agar tahan lama yang dapat dibawa pada ibu bepergian atau sedang bekerja serta menyiapkan baju menyusui bagi ibu agar 
Tabel 4. Pemberian ASI Eksklusif Ibu Menyusui pada Bayi Usia 6-12 Bulan.

\begin{tabular}{lcc}
\hline Pemberian ASI & Frekuensi & $\mathbf{\%}$ \\
\hline Ya & 16 & 53,3 \\
Tidak & 14 & 46,7 \\
\hline Total & $\mathbf{3 0}$ & $\mathbf{1 0 0}$ \\
\hline
\end{tabular}

pada saat menyusui merasa lebih nyaman. Pemberian ASI eksklusif pada Bayi Usia 6-12 bulan di Posyandu Dewisari.

Pada Tabel 4 diatas, dapat diketahui bahwa sebagian besar responden di Posyandu Dewisari yang diwawancarai memberikan ASI secara eksklusif kepada bayinya. Pemberian ASI eksklusif adalah bentuk pemberian asupan makanan yang dilakukan untuk bayi tanpa diikuti pemberian cairan tambahan selama 6 bulan sejak lahir. Cairan lain yang dimaksud diantaranya air, madu, susu formula, atau makanan padat seperti bubur, biskuit dan pisang (Roesli, 2008). Bayi yang sehat tidak memerlukan makanan tambahan selain ASI sampai 6 bulan, setelah itu baru diperkenalkan dengan makanan padat. Akan tetapi pemberian ASI tetap dapat dilakukan hingga umur 2 tahun.

Pengalaman yang didapat oleh seorang ibu akan berhubungan dengan pemberian ASI eksklusif. Pengalaman tersebut bisa didapatkan dari pengalaman yang dialami sendiri ataupun pengalaman yang diperoleh dari orang lain. Pengalaman yang dialami ibu dapat membentuk penghayatan stimulus. Pengalaman yang didapatkan seorang ibu sebelumnya cenderung mendorong seorang ibu untuk melakukan hal yang sama lagi, karena menurut penilaiannya, pengalaman tersebut bermanfaat bagi perkembangan dan pertumbuhan bayinya. Kesehatan dan keadaan fisik ibu mempunyai pengaruh besar terhadap pemberian ASI eksklusif. Misalnya, apabila payudara ibu sakit atau mengalami gangguan, ibu akan mengalami masalah dalam pemberian ASI eksklusif kepada bayi.

Penelitian ini menggunakan hasil uji data dengan rumus Kendal Tau pada responden dan diperoleh nilai $p_{\text {value }}$ sebanyak 0,001 . Penentuan hipotesis dalam penelitian diterima atau ditolak apabila nilai $p_{\text {value }}$ dibandingkan dengan nilai signifikan $(\alpha)$. Apabila $p_{\text {value }}$ memiliki nilai yang lebih kecil dari $\alpha$ maka hipotesis diterima dan begitu pun sebaliknya. Dalam penelitian ini digunakan nilai $\alpha$ sebesar $5 \%$, jika dihubungkan dengan nilai $p_{\text {value }}$ yang diperoleh maka disimpulkan nilai $p_{\text {value }}$ lebih kecil dibanding nilai $\alpha$ yang dapat digunakan untuk penelitian ini. Oleh karena itu dapat disimpulkan, bahwa hipotesis penelitian diterima yakni adanya dukungan suami kepada ibu menyusui terkait dengan pemberian ASI eksklusif kepada bayi.

Hasil penelitian ini telah sesuai dengan penelitian yang telah dilakukan oleh Suprobowati pada tahun 2007. Dari hasil penelitian tersebut dapat dijelaskan bahwa dukungan keluarga memiliki hubungan yang selaras dengan pemberian ASI eksklusif. Hubungan tersebut memiliki arti bahwa dukungan yang diberikan oleh keluarga secara baik akan memberikan dampak pada ibu untuk memberikan ASI eksklusif kepada bayinya dengan baik. Menurut Suprobowati (2007), terdapat 59 orang $(78,7 \%)$ dari 75 orang yang sudah diteliti dan mendapat dukungan baik dari keluarganya. Hasil uji analisis data menggunakan chi quadrat yang diketahui bahwa terdapat adanya hubungan antara pengetahuan dengan perilaku ibu bekerja dengan pemberian ASI yang memiliki nilai koefisien kontingesti sebanyak 0,69 (kuat).

Penelitian ini menunjukkan hasil apabila dukungan suami memiliki hubungan terhadap perilaku responden yaitu ibu menyusui yang memberikan ASI eksklusif secara penuh kepada bayinya. Suami mempunyai peran yang penting dalam pengambilan keputusan seorang ibu dalam pemberian ASI eksklusif. Menurut Roesli (2008), dalam rangka penyuksesan pelaksanaan program ASI eksklusif selama 6 bulan, suami wajib mendapatkan penjelasan dan berbagai informasi tentang peran dirinya dalam pelaksanaan program tersebut.

Suami memiliki suatu peran yang penting dalam kegiatan pemberian ASI eksklusif, karena peran tersebut dapat meningkatkan pemberian ASI eksklusif yang dilakukan oleh ibu. ASI eksklusif dapat bermanfaat karena dapat meningkatkan kualitas kehidupan anak. Namun, kondisi 
tersebut banyak yang tidak dimengerti suami. Suami memiliki peran seperti menciptakan kondisi lingkungan yang nyaman bagi ibu sehingga kondisi fisik dan psikologis mereka selalu sehat. Selain itu, dukungan suami juga dapat memberikan rasa aman dan meyakinkan ibu bahwa dia mampu menyusui pada bayi sampai usia 6 bulan.

Dukungan suami yang terkait pemberian ASI eksklusif berupa kemampuan suami yang digambarkan sebagai pengetahuan suami terkait ASI eksklusif. Hal tersebut akan mempengaruhi dukungan dan pola asuh yang dapat diberikan kepada anggota keluarga lainnya. Adanya bentuk dukungan dari suami, dapat mempengaruhi ibu menyusui untuk semakin optimis dan percaya diri dalam memberikan ASI eksklusif pada bayinya.

\section{KESIMPULAN}

Ada hubungan kuat antara dukungan suami terhadap pemberian ASI eksklusif pada ibu menyusui dengan bayi yang berusia 6 sampai 12 bulan di Posyandu Dewisari.

Agar dukungan suami terhadap pemberian ASI eksklusif dapat merata, maka diperlukan sosialisasi program Promosi Kesehatan yang dapat disebarluaskan melalui berbagai media komunikasi (media cetak ataupun media elektronik) untuk pasangan suami istri, keluarga dan lingkungan.

Suami sebagai kepala rumah tangga perlu menjalankan perannya sebagai support system dengan memberikan dukungan informatif, penghargaan, emosional dan instrumental selama ibu menyusui sampai bayi berusia 6 bulan agar ibu dapat memberikan ASI eksklusif.

Suami yang bertekad untuk memberikan dukungan kepada istri dalam pemberian ASI eksklusif dapat membentuk peer group, sehingga suami mempunyai kesempatan dalam membagi pengalamannya dalam mengatasi masalah atau kendala dalam pemberian ASI eksklusif. Selain hal tersebut, suami dapat memberikan dukungan intensif kepada istri dengan menyediakan fasilitas yang mendukung kegiatan istri selama menyusui. Dukungan tersebut berupa penyediaan sarana dan prasarana untuk penyimpanan ASI seperti almari es (kulkas) apabila produksi ASI dari ibu berlebihan, hal tersebut dilakukan agar ASI yang berlebih dapat disimpan dan tahan lama. Sehingga ASI tidak terbuang sia-sia. Dukungan terhadap ibu menyusui juga dapat dilakukan dengan menyediakan perlengkapan pakaian untuk menyusui yang dapat digunakan ibu dalam mendapatkan kenyamanan pada saat ibu menyusui bayinya.

\section{DAFTAR PUSTAKA}

Aprilia, Y. 2010. Analisis Sosialisasi Program Inisiasi Menyusu Dini dan Asi Eksklusif Kepada Bidan di Kabupten Klaten. Thesis. Universitas Diponegoro Semarang.

Ariani. 2010. Ibu Susui Aku!. Bandung: Khazanah Intelektual.

Asnawi. N. 2009. Social Support and Behavior Toward Others (Dukungan Sosial, dan Perilaku Terhadap Orang Lain) Suatu Tinjauan Psikologi. Tersedia $\mathrm{di}<$ http://digilib.unimus.ac.id $>$ (1 Januari 2013).

Departemen Kesehatan RI. 2005. Ibu Bekerja tetap Memberikan Air Susu Ibu (ASI) dan Ibu Rumah Tangga selalu Memberikan Air Susu Ibu. Jakarta: Departemen Kesehatan RI.

Hidayat. 2009. Ilmu Perilaku Manusia. Trans Info Media: Jakarta.

Human Development Report. 2010. The Real Wealth of Nations: Pathways to Human Development. USA: United Nations Development Programme (UNDP).

Prasetyono, S.D. 2009. ASI eksklusif. Yogyakarta: Diva Press.

Profil Kesehatan Daerah Istimewa Yogyakarta. 2013. Tersedia di<http:// www.depkes.go.id/resources/download/ profil/Profil_Kes_Provinsi_2012/14 Profil_Kes.Prov.DiYogyakarta_2012. pdf> (1 Januari 2013).

Profil Kesehatan Kabupaten Bantul. 2012. Tersedia di<https://www.scribd.com/ doc/176550712/Profil-Bantul-2012> (2 Januari 2013).

Proverawati, A., dan Rahmawati, E. 2010. Kapita Selekta Asi \& Menyusui. Yogyakarta: Nuha Medika. 
Roesli, U. 2008. Inisiasi Menyusui Dini. Jakarta: Pustaka Bunda.

Roesli, U. 2008. Manfaat ASI dan Menyusui. Jakarta: Fakultas Kedokteran Universitas Indonesia.

Sherwood, L. 2009. Fisiologi Manusia dari Sel ke Sistem. Jakarta: EGC.

Smet, B. 1994. Psikologi Kesehatan. Jakarta: Gramedia Widiasarana Indonesia.

Sulistyaningsih. 2011. Metodologi Penelitian Kebidanan Kuantitatif-Kualitatif. Yogyakarta: Graha Ilmu.

Suprobowati. 2007. Hubungan dukungan Keluarga dengan Pemberian ASI Eksklusif pada Bayi 0-6 Bulan di Puskesmas Sleman Yogyakarta. Karya Tulis Ilmiah di II Kebidanan, Universitas Aisyiyah Yogyakarta.

Suradi, R. 2008. Manfaat ASI dan Menyusui. Jakarta: Fakultas Kedokteran Universitas Indonesia.
Suradi, R., Hegar, B., Partiwi, A.N., Marzuki, N.S., dan Ananta, Y. 2010. Indonesia Menyusui. Jakarta: IDAI.

Survei Demografi dan Kesehatan Indonesia. 2007. Angka Kematian Bayi. Tersedia di https://www.scribd.com/doc/17909311/ Survei-Demografi-Kesehatan-Indonesia2007> (1 Januari 2013).

Survei Demografi dan Kesehatan Indonesia. 2007. Menyusui Pada Bayi. Tersedia di $<$ Https:/Www.Scribd.Com/Doc/17909311/ survei-demografi-kesehatan-indonesia2007>(1 Januari 20134).

Widya, W., Wahyu, R., Hartiti, T., dan Samiasih. 2011. Lama Waktu Pemberian Makanan Pendamping Asi di Usia Dini dengan Status Gizi Bayi (6-12 Bulan) di Kelurahan Tlogourang Wilayah Kerja Puskesmas Boja. Jurnal Keperawatan. Volume 4 No 2 Oktober 2011: pp. 133-146. 